ARTICLE

DOI: $10.1057 /$ s41599-018-0142-4

\title{
Sexual rejuvenation and hegemonic masculinity in C.P. Snow's suppressed novel New Lives for Old (1933)
}

\author{
Catherine Oakley (D) ${ }^{1}$
}

\begin{abstract}
The English physical chemist C.P. Snow is most renowned for his 1959 Rede Lecture The Two Cultures and the Scientific Revolution in which he lamented the intellectual divide between the sciences and the humanities. His work as a prolific writer of fiction, however, is less well-known, though he wrote seventeen novels over the course of his lifetime. New Lives for Old, published anonymously in 1933 and subsequently suppressed by the author, is the most obscure of these works. The novel's fictional protagonist Billy Pilgrim, a professor of biophysics at Kings College, London, develops a technique for synthesising a human sex hormone which can prevent the atrophy of the ageing body. The first part of this paper draws on new archival documents to sketch the background to the novel's publication and suppression. The second part situates the novel in relation to the under-explored subgenre of rejuvenation fiction from the early decades of the twentieth century, emphasising the dynamic exchange of rejuvenation discourses during this period across the medical and cultural spheres. The third and final part draws on the sociological concept of hegemonic masculinity to illuminate the book's androcentrism and its sexism, tracing the ways in which C.P. Snow mobilises the gendered concept and practice of medical rejuvenation to navigate perceived threats to male privilege and authority.
\end{abstract}

\footnotetext{
${ }^{1}$ University of Leeds, Leeds LS2 9JT, UK. Correspondence and requests for materials should be addressed to C.O. (email: C.M.C.Oakley@leeds.ac.uk)
} 


\section{Introduction}

B orn in Leicester and educated at his local grammar school and college, Charles Percy Snow won a scholarship to Christ's College, Cambridge in 1928 aged 23, and completed his $\mathrm{PhD}$ in Physical Chemistry there, becoming a Fellow of the college between 1930-1935. He subsequently led a prestigious career in the senior civil service, was recognised in the Queen's Honours List in 1957, and was made a life peer in the House of Lords in 1964. Snow's primary reputation is as a scientist, and academic scholarship and public interest have converged largely on the period from the late 1950s onwards, following his influential Rede Lecture The Two Cultures and The Scientific Revolution (Snow, 1959).

This critical narrative has obscured Snow's earlier life and work. In fact, Snow considered himself as much a writer as a scientist. Throughout his life, he authored seventeen novels, twelve nonfiction books, nine plays, and hundreds of book reviews, articles, and lectures. His novel New Lives for Old, which he published anonymously in 1933 and subsequently suppressed, is one of his earliest and most inconspicuous works. The novel focuses on three male protagonists: Billy Pilgrim, a Professor of Biophysics and at King's College, London (aged sixty-five at the opening of the novel), his assistant David Callan (aged twentyfive), and Pilgrim's friend Vanden, a writer (in his sixties). The book moves between the viewpoints of its major characters, and is divided into three parts. Part I, 'Before the Change', focuses on Pilgrim and Callan's discovery of a process for synthesising a hormone called collophage, which offers renewed vigour and sexual drive to older people over the course of thirty additional years of life. In the first chapters of the novel, Callan expresses his objections to Pilgrim's plan to make the discovery public, citing the possible adverse socio-political consequences. Pilgrim eschews Callan's call for a more considered response, defies requests for an embargo from key political figures, and releases news of the rejuvenation technology. Part II, 'The Old Grow Young', focuses on the personal relationships of the main characters. At its centre is a love triangle. Following his rejuvenation, Pilgrim finds himself in love with Alison, a young woman first introduced in Part I as Callan's girlfriend. The two begin a romantic relationship which is interrupted when Vanden, who has also been rejuvenated, persuades Alison to leave Pilgrim and begin a relationship with him instead. Several subsequent chapters trace the development of this relationship, which ultimately proves to be shortlived: Alison leaves Vanden and returns to England. Part II closes with Alison and Pilgrim reunited, despite Vanden's attempts to reclaim Alison's affections. Part III: 'The Young Grow Old', is set thirty years after the discovery. Through a first-person written account by Callan-now in his mid-fifties-we learn of the political, social, and economic consequences of rejuvenation in Britain, which are almost universally negative. Rejuvenation has 'heightened and sharpened' existing class tensions and economic instabilities (Snow, 1933d, p. 291). The high cost of the treatment has created a two-tier society of a rejuvenated elite, on the one hand, and an ageing poor-already dealing with the fallout of the 1929 financial crash-on the other. In the final chapters of the novel, Pilgrim and Vanden hide in a London flat near the BBC as revolution descends. A gas attack forces them to seek shelter in Kings College, London, where Pilgrim eventually sacrifices himself to retrieve a supply of gas masks that will save the others.

In this article, I draw on approaches from literary studies, history of science, and the sociology of gender to offer a new reading of the novel. My analysis is divided into three parts. In Part I, I supply new archival information on the background to the novel's development, publication, and suppression. In Part II, I illustrate the scientific concerns of the early 1930s which directed the novel's thematic focus. I also situate the text in cultural context, including in relation to comparable speculative fictions of rejuvenation and other key literary influences. Finally, in Part III, I examine the sexist ideology at work in the novel's representation of rejuvenation using conceptual and critical tools from biographical criticism and gender studies.

This interdisciplinary approach seeks to locate the novel as a textual space in which the young Snow was navigating a range of intellectual, social, and personal issues at a particular historical moment. The novel-itself set in London in the early 1930sreflects concerns with the uncertainties of scientific progress, the social and political instability of the post-crash years, the complexities of male friendships and of romantic relationships, and the prospects of male sexual satisfaction-and authority-across the life course. To unravel these discursive entanglements more fully, I draw in later sections on the sociological concept of hegemonic masculinity. In so doing, I make newly visible the ways in which Snow's work as a writer was expressive of his subject-position as an aspiring literary author, a scientific scholar, and a member of an elite patriarchal social milieu.

In her book Living a Feminist Life, the academic and activist Sara Ahmed (2017) draws on her experiences of university education to emphasise the continuing disavowal of gender and equality as central areas of scholarly interest across a range of disciplines. As a student, Ahmed found herself increasingly ill-atease with the marginalisation of gender politics in the seminar room. 'I began to wonder whether doing theory was about engaging with a body of work by putting questions like phallocentrism or sexism into brackets', she writes. 'I was concerned with how statements made by the teacher, like "This is not about women", were used to bypass any questions about how the figure of woman is exercised within a male intellectual tradition' (p. 8). Ahmed's anecdote enunciates a reality in which the 'bracketing' of gender and equality as subordinate topics of critical conversation in scholarly discourse function as acts of continuing disengagement and diminishment.

The field of the history of science is no exception to this. There has been progress: Donna Haraway's insistence on the 'contestability' of scientific and technological knowledge has opened up radical new possibilities for the feminist historian of science to revise and re-envision existing historical narratives and ideological categories in the study of health and the human body. In addition, Catherine Waldby's work on the 'phallocentric' and 'homosocial' construction of AIDS has demonstrated how 'biomedical practices can...be understood as political practices, seeking to enforce compliance with conservative regimes of sexuality' (1996, p. 7). Waldby's scholarship remains a leading example of a critique alert to 'the deployment of, and unacknowledged reliance on, culturally intelligible fantasies and mythologies within the terms of what claims to be a system of pure logic' (Waldby, 2000, p. 137). But the development and application of a feminist theoretical trajectory-in the history of science as elsewhere-is an ongoing project. This article is a contribution to such progressive work. I argue that a critical consideration of masculinity and misogyny in New Lives for Old is integral to a full understanding of the text's scientific conception and representation. Examining the novel through this lens facilitates nuanced insights into the complex, interconnected medical, social, cultural and ideological discourses that shape visions of human regeneration.

\section{Part I: Publication and suppression}

New Lives for Old has received little scholarly attention to date. Nicholas Tredell's (2012) book C.P. Snow and the Dynamics of Hope is the first study of Snow's literary work to consider the 
novel, identifying some background to its publication, noting its incorporation of elements from different genres, and outlining some key themes. ${ }^{1}$ Beyond this, Susan Squier (2004) has devoted a couple of paragraphs to the book within her broader exploration of rejuvenatory and reproductive technologies in medicine and literary fiction in the 1920s and 1930s (pp. 159-160). Lack of critical engagement with the novel is unsurprising, and not just because of the cloak-and-dagger circumstances of its production and its vaporous afterlife. The book's prose is alternately flat and turgid, its structure loose and incoherent. Its characterisations tend towards either vapid egoism (in the male protagonists) or hackneyed stereotype (in the female characters). What the novel lacks in literary merit, however, it more than compensates for as an underexplored site of the 'biomedical imaginary'; that which Catherine Waldby describes as 'the speculative, propositional fabric of medical thought, the generally disavowed dream work performed by biomedical theory and innovation' (p. 136). Drawing on Waldby's formulation, Squier has underscored the critical value of literature beyond its aesthetic and formal elements. Speculative fiction in particular, she notes, is the subject of 'a fantasmatic investment' (p. 154); it functions as a kind of textual laboratory in which the intricacies and potential implications of medico-cultural ideas are tested imaginatively. Viewed in these terms, Snow's exploration of the nexus of sexual potency, ageism, and medical technology presents an illuminating casestudy in how literary materials during this period functioned as dynamic spaces within which gendered cultural and medical ideas around human regeneration intersected and re-made each other.

No materials pertaining to New Lives for Old are held at the C. P. Snow archive at the Harry Ransom Center, Texas. But a file containing a mixture of hand-scripted and typewritten original documents-including correspondence between Snow and his literary editor, readers' reports, and rights and reprint requestssurvives at the archive of the book's publisher Gollancz in London. Pieced together, the information in that file suggests it is likely that Snow began the draft of the book in 1932. He submitted the manuscript initially to the publishing house Heinemann, which had published his first book, Death Under Sail, earlier that same year. Managing director Charles S. Evans commissioned a reader's report on the new draft from the Irish novelist and playwright Kate O'Brien. ${ }^{2}$ She was ambivalent. The author's style, she reported, was 'pedestrian, but efficient'; she struggled to imagine that the book could be a success: 'As it stands', she wrote, 'it is neither very good nor very bad; it is alternatively interesting and embarrassing' (O'Brien, (undated) $\mathrm{p}$. 4, 5). By early 1933, Snow had taken the manuscript to the Gollancz Publishing Company. Its head, Victor Gollancz, passed it on to Gerald Gould, a writer and journalist working as his chief manuscript reader. Gould's verdict was decidedly more effusive than O'Brien's had been: it was, he believed, 'a work of remarkable variety and impressiveness', despite its 'many faults' (Gould, 1933 , p. 7). He recommended to Gollancz that he publish the book on account of its 'exceptional intellectual value' and its considerable sales potential, suggesting that 'it ought, with luck, to make some slight sensation' (p. 8). Snow worked on edits to the manuscript and New Lives for Old was published in July 1933.

However, the dust jacket of the published title did not bear the author's name, attributing it instead only to 'One of our Younger Scientists'. The only explanatory context for Snow's motivations in anonymising and suppressing the book in this way are some brief comments made some years later by his brother Philip:

Charles was very reluctant to talk about this book...New Lives for Old came out anonymously because, as he said, he was at the time in line for a job which this authorship might have prejudiced...Efforts by publishers to have [the book] reprinted were never sanctioned...My copy is inscribed 'To Philip. The book which will not appear again. C.P. Snow' (Snow, 1982, p. 35).

The precise reasons for Snow's anxiety about the reputational risk the book would pose are unclear, but several factors may have contributed to his decision to anonymise. The novel's interest in polemical questions surrounding the social responsibility of the scientist emerged from heated political debate among Snow's close friends and colleagues at Cambridge-a number of whom were radical leftists-about the modern social function of science. ${ }^{3}$ However, Snow himself was, in his own words, 'very little' of a socialist, aligning himself broadly with 'the intellectual left, not the trade-union left' in his early life (Halperin, 1983, p. 40, 66). In addition, Snow may have felt that the book's satirical elements risked compromising his scientific career. ${ }^{4}$ It's also conceivable that the subject matter of sexual rejuvenation-hardly the output expected from an aspiring student of serious sciencemay have led Snow to disavow his authorship of the book. Kate O'Brien's reader's report had expressed concern that 'there is a great deal of sex-stuff, and most of it has the unexpected effect of making one uncomfortable' (O'Brien, p. 6). Whatever the reasons, it is likely that the decision to publish anonymously impinged on the novel's success. A month after its release, Snow wrote to Victor Gollancz, asking him to confirm his impression that the novel had 'fallen firmly flat' (Snow, 1933c). Gollancz replied to say that sales had indeed been modest (around 1500 copies), and that it had 'never shown any signs at all of catching on in a big way'. $\mathrm{He}$ added to this his view that 'it is one of those books with a small sale that tends to establish an author's reputation-if only the author were not anonymous!' (Gollancz, 1933). The novel would not be reprinted, and Snow would never acknowledge its existence publicly. ${ }^{5}$

\section{Part II: The rejuvenation fiction sub-genre}

Despite the book's commercial failure, Victor Gollancz's instinct to publish it would likely have made sense at the time. In its specific focus on biomedical solutions to the physiological and social condition of ageing, New Lives for Old inserted itself readily into a distinctive category of medical science fiction from the period: rejuvenation fiction. Existing scholarship on rejuvenation fiction is piecemeal, and fictional rejuvenation texts have typically occupied a peripheral role in historical accounts of medical rejuvenation practices. ${ }^{6}$ However, an approach to genre that combines (a) the classification of shared formal characteristics, and (b) a rhetorical theory of genre as a creative response to a recurring situation (Devitt, 2004) indicates that a range of popular fictions published in the UK and the US in the last decades of the nineteenth century and the first decades of the twentieth century represented a historical subgenre of rejuvenation fiction.

These popular stories all featured ageing protagonists who attempted to reclaim their youth through quasi-medical means (elixirs, surgeries, blood transfusions, irradiation), with varying degrees of success. They were published during a period of medical advances in the practices of gerontology, endocrinology, and surgery, and amidst extensive public debates about the role of older people in society, the introduction of pensions, and the effects of the First World War on intergenerational relations. In addition, the growth of popular print culture and the rise of the cinematic screen star generated a post-war 'cult of youth', fed by new standards of beauty. Rejuvenation fictions thus represented key textual sites in which a range of medical, social, and cultural discourses converged, and in which they were negotiated and reformulated.

The literary scholar Martin Willis has drawn attention to the limitations of existing genre criticism in addressing the 
complexity of encounters between scientific and cultural forms, noting that this work often fails to engage with the scientific contexts of imaginative fictions. Willis's insistence on 'a continuously cyclical process of influence and self-reflection within scientific, social and cultural disciplines' is an invitation to an interdisciplinary practice that demonstrates 'how reading of science fiction texts benefit from extended exposure to the specific scientific histories that were so important in their making' (Willis, 2006, p. 236, 6). Reading New Lives for Old as part of a subgenre of rejuvenation fictions that correlated with contemporaneous practices in rejuvenation science offers a new case-study in this dynamic discursive traffic between science and culture.

The correspondences between medical and cultural discourses of rejuvenation in the decades around the turn of the twentieth century can be mapped as follows. The first phase of rejuvenation fiction in the 1880s and 1890s corresponded with the work of the American neurophysiologist Charles Brown-Séquard around the rejuvenating potential of a chemical solution containing seminal extracts from humans and animals. ${ }^{7}$ The genre picked up again in the late 1910s and early 1920s, following the work of the physicians Eugen Steinach and Serge Voronoff, whose surgical glandular operations-which claimed to restore the body's youthful function and appearance-generated a cultural phenomenon. ${ }^{8}$ It was in this second phase that rejuvenation really took hold in the public imagination. The topic received extensive news coverage across the UK and the US, and some popular fictions drawing on the topic became both bestselling books and hit film adaptations. ${ }^{9}$ Snow's foray into rejuvenation fiction marked the third and final phase of the genre. By the late 1920s, the procedures offered by Steinach and Voronoff were still popular and widely-reported, though criticism was growing (Hamilton, 1986, pp. 121-135). The Austrian writer Vicki Baum's bestselling 1928 novel Stud. Chem. Helene Willfüer - translated into English and published as Helene in 1932-followed the personal and professional life of a female scientist who discovers and successfully commercialises a rejuvenation formula. The Australian-born writer Isabel Mary Mitchell's Yet in My Flesh (1933) which followed two rival scientists working on formulas for artificial rejuvenation of the body at a Welsh laboratory, was published just weeks before New Lives for Old. It featured a storyline including rejuvenation experiments on rats, followed by a human trial on a woman approaching menopause. $^{10}$

Carolyn Miller's definition of genres as 'typified rhetorical actions based in recurrent situations' (Miller, 1984, p. 159) offers a useful framework for considering the responsiveness from the reading public that Snow and Gollancz may have hoped for, or expected, on publishing New Lives for Old. The novel's contemporary critics recognised the book as a rhetorical invitation for its readers to mobilise their 'implicit knowledge' (Ryan, 1981, p. 112) of science fiction as a distinctive discursive response to a specific social phenomenon: that of biomedical and technological change. The scientific practices of rejuvenation and their exploration in the subgenre of rejuvenation fiction were key elements of this knowledge. But two literary critics assessing Snow's novel on its release drew on another shared cultural referent from the early twentieth century in their references to the work of H. G. Wells. The Saturday Review proclaimed that 'there has not been anything better in "scientific romance" since $\mathrm{Mr}$. Wells in his famous first phase' (A.B., 1933a, p. 158), while in the New Statesman, E.C.B. Jones stated New Lives for Old recalled the 'satire and psychology' of Wells' 'best work', albeit without the skill in narrative 'machinery or management' (Jones, 1933, p. 136). Snow openly acknowledged Wells' influence on his early writing (Afanasyeva, 2002), and the title of his second book bears similarities with New Worlds for Old (1908), one of several nonfiction books and pamphlets Wells wrote in the early part of the twentieth century as he sought to address the history and future of socialist reform. ${ }^{11}$ Wells had imagined popular worker's uprisings and societal collapse among the consequences of technological innovations in The Time Machine (1895), The Sleeper Awakes (1910), and The World Set Free (1914): in New Lives for Old, Snow expressed his own interest in the potential of scientific discoveries to effect social transformations.

\section{Part III: The gendered dimensions of rejuvenation technology} The year 1932, during which Snow was working on New Lives for Old, also saw the release of Aldous Huxley's Brave New World (1932). Huxley's novel shared with Snow's novel-in-the-making a vision of a speculative future transformed by medical engineering of the human body, and its negative consequences for social and private lives. In addition to their mediations of discourses on biomedical technologies, both fictions also offered responses to another 'rhetorical situation' (Devitt, 2004, p. 13): the limitations of both capitalism and communism in the immediate aftermath of the economic and political crises of the late 1920s. And like Brave New World, New Lives for Old registered both the initial promise of sexual liberation for both sexes offered by new medical technologies and the shifting dynamics of power in relationships between men and women as they are mediated by the consequential transformations.

The gendered implications of rejuvenation technology present themselves from the very beginning of New Lives for Old. In a scene in the early pages of the novel, huge crowds take to the streets of London to celebrate the prime minister's announcement that a rejuvenation formula has been discovered. Yet, amidst this atmosphere of collective jubilation, Pilgrim witnesses an act of male sexual coercion which presages the gendered imbalances of power that the new discovery will serve to focalise and intensify:

There were shouts and clamouring cheers which grew in strength into one long crescendo; in front of Vanden, someone was crying hysterically, the tears streaming down his face; at the side of Pilgrim, a man seized a woman by him and kissed her mouth, while her nails tore the skin from his face. (Snow, 1933d, p. 94)

New Lives for Old is an androcentric book. We might perhaps expect the novel to privilege male experience and perspectives given the male-dominated milieu in which it is set and within which Snow composed it. ${ }^{12}$ Yet, the novel is not only a document of male privilege, but of an embedded and diversely-expressed misogyny. Rejuvenation here is a tool wielded by a scientific and social male elite to manipulate female behaviour and to mould an ideal sexual womanhood. The attitudes and behaviours of the two central male characters in the novel towards women typically involve objectification, intimidation, and coercion, and culminate on one occasion in physical violence.

In the sections below, I explore how this aggressive male idealism also operates in relation to the prospect of sexual rejuvenation for both sexes. A critical examination of these power dynamics reveals that Snow's novel does not just engage with questions around scientific responsibility and the potential socioeconomic consequences of anti-ageing technologies. It also envisages rejuvenation as an idea that generates a profound crisis of masculinity and a threat to the very fabric of patriarchal Western society.

Fixing a critical spotlight on the book's misogyny is instrumental in revealing new perspectives on how rejuvenation and regeneration have been envisioned as scientific possibilities. In this sense, my work here is part of a continuing tradition of feminist theory and scholarship that has grown across disciplines since the 1970s and sought to demonstrate the implications and 
consequences of a scientific institutions and discourses as sites of male power (Anon, 2018). The critic Darko Suvin (1979) has coined the term 'novum' to describe the scientifically-plausible inventions used in science fiction (sf) narratives (p. 63). As summarised by Istvan Csicsery-Ronay, (2003);

The novum is the historical innovation or novelty in an sf text from which the most important distinctions between the world of the tale from the world of the reader stem...In practice, the novum appears as an invention or a discovery around which the characters and setting organize themselves in a cogent, historically plausible way. The novum is a product of material processes; it produces effects that can be logically derived from the novum's causes, in the material and social worlds. (pp. 118-119)

In New Lives for Old, the novum of hormonal rejuvenation both emerges from, and reproduces, deeply gendered medical, social, and cultural discourses on the uses and consequences of age-reversing technologies. A reading of Snow's novel thus represents a valuable opportunity to bring feminist perspectives to bear on a text located at the intersection of literary studies and the history of science. Sharon Crasnow et al. (2015) note that 'feminists have identified the sciences as both a source and a locus of gender inequalities'. They elaborate:

The worry here is that the sciences are not just superficially or inadvertently androcentric-male-centred in the questions they ask, in their claims and practice, their institutions and authority, their implications for the lives of women and for those marginalized within normative sex/gender systems-but are fundamentally sexist; they embody deep and systematic gender bias by which women, and any interests, perspectives, or insights associated with them, are disvalued and marginalised.

Snow's novel both reflects and reproduces the androcentrism and systematic gender bias Crasnow et al. identify here. The new hormone treatment discovered by Pilgrim and Callan sits at the intersection of reproductive and life-extension strategies. It slows the ageing process, reinvigorates the body, and restores the sex drive. But although the treatment is made available to both sexes, the novel frames the discovery primarily in terms of its benefits for the ageing man. In fact, this focus on male rejuvenation is at odds with the scientific reality of rejuvenation science by the early 1930s. The feminist and science studies scholars Nellie Oudshoorn (1994) and Susan Squier (2004) have each emphasised the socio-cultural forces that informed the development of sex endocrinology and its practices in the 1920s and 1930s. Oudshoorn has noted that by the third decade of the twentieth century, physicians working with sex hormones were keen to eschew associations with quackery that had surrounded research into the male testes, and so turned their interest instead to the practice of gynaecology, which offered a readily 'appropriate institutional context' for such research (p. 103). Meanwhile, Squier has argued that a key characteristic of the rejuvenation phenomenon of the early twentieth century was its 'gender asymmetrical "uptake" ' as a medical scientific innovation: a development in-keeping with a historical pattern from the eighteenth century onwards in which women's bodies become the primary focus of scientific and medical interventions (p. 154).

Squier's 'gender-asymmetrical social uptake' of rejuvenation by and for female bodies is not evident in New Lives for Old. Male patients are rejuvenated with ease, but for female patients, 'the physiological problem's more complicated'. Pilgrim notes: 'Whether the desire for children will return along with the desire for men; and, if it does, whether it'll be possible to make any readjustment to satisfy it-problems like that I just can't answer'
(Snow, 1933d, p. 34). From the perspective of the male scientist, the medicalised, aged female body is a cipher here, its functions capricious, its passions unintelligible. Female sexual drive is inscrutable: rejuvenation will not necessarily clarify the distinction between biological urge (desire for children) and nonreproductive heterosexual pleasure (desire for men). In Part III of the novel, Callan, surveying the repercussions of the discovery in retrospect, reports that while rejuvenation has ascribed reproductive power to men, it has not restored fertility to women. Whilst 'almost all rejuvenated men are physically capable of having children', all rejuvenated women are sterile. The consequences of this are a society in which rejuvenated men and 'ordinary males' compete sexually for young women (Snow, 1933d, p. 304). Meanwhile, female rejuvenation is fruitless: older women are free to embrace 'reckless' love affairs only when divested of reproductive choice.

Whilst all the male characters in the novel who wish for rejuvenation treatment embrace and receive it, the treatment has a mixed success rate for female characters. Pilgrim's friend Simone finds that the transformation is not physically possible for her because her hormonal type is incompatible with the therapy. Simone is all too aware that her unsuccessful rejuvenation attempt constitutes a failure to meet the new medico-social standard of acceptable female self-presentation. In her subsequent resolve to open a beauty parlour to help rejuvenated women look even younger, she takes on the proxy role of rejuvenation doctor, committed to the cause of shaping an ideal aesthetic womanhood through entrepreneurial means. Elsewhere, New Lives for Old registers a gendered ambivalence about female rejuvenation. Whilst the re-formation of a woman's body to male specification is desirable in principle, Snow does not express much interest in the experiences or emotions of the rejuvenated woman. There is some suggestion that the therapy is sexually liberating for older women: Alison's mother Mrs Byrne takes a young lover, and later in the novel, divorces her husband for him. But her twenty-fouryear-old daughter-nubile and unrejuvenated-is the focal point for the older men's fervour.

In order to further unpack the gendered implications of rejuvenation in Snow's novel in my remaining analyses, I want to draw on the idea of hegemonic masculinity. A conceptual tool first introduced by the gender sociologist Raewyn Connell in the late 1980s, hegemonic masculinity is consistent with feminist analyses of patriarchy. Its primary concern is 'how particular groups of men inhabit positions of power and wealth, and how they legitimate and reproduce the social relationships that generate their dominance' (Carrigan and Connell, 1985, p. 592). In developing the concept, Connell drew on Antonio Gramsci's theories about the ways in which power is obtained and sustained socially to offer 'an analogue, in gender terms, of power structure research in political sociology-focusing the spotlight on a dominant group' (Connell and Messerschmidt, 2005, p. 832).

Hegemonic masculinity describes a normative standard of idealised masculinity that is socio-culturally constructed, reproduced, and incentivised. 'Centrally connected with the institutions of male dominance, not all men practice it, though most benefit from it' (Donaldson, 1993, p. 645). As the concept of hegemonic masculinity was taken up across diverse disciplines between the late 1980s and the early 1900s, Connell published a follow-up essay with James W. Messerschmidt which revisited the concept in the light of its wide-ranging (mis)applications. Engaging substantively with a range of critiques, the authors sought to clarify, above all, that hegemonic masculinity does not describe a single character type, nor a catalogue of (negative) personality traits, but is instead a series of practices, historically and geographically situated, and 'accomplished in social action' (Connell and Messerschmidt, 2005, p. 836). 
Using the concept of hegemonic masculinity as a critical tool, we can read New Lives for Old as a cultural text produced from a particular subject position at a specific moment in 'the historical construction and reconstruction of hegemonic masculinities' (Connell and Messerschmidt, 2005, p. 846). At a fictional level, the agents of this practice are the white, male, British ruling classes: the scientific and political elite of Cambridge and Westminster in the early twentieth century. Pilgrim and Vanden are akin to the 'organic intellectuals' that Gramsci (1998) identifies as the primary actors in maintaining the hegemonic order. They are also examples of those whose institutional positions of power enable them to 'regulate and manage gender regimes; articulate experiences, fantasies, and perspectives; reflect on and interpret gender relations' (Gramsci, 1998, p. 646).

The challenge to hegemonic masculinity posed by the new sexual technology of rejuvenation-and the work of retrenchment that this inspires in the novel's male characters-are primary discursive currents in New Lives for Old. Rejuvenation represents the possibility of augmenting male sexual function and prowess. But its widespread efficacy in older males, and its ready availability to female patients (although taken up unevenly and not without complications), forces discursive renegotiations of idealised masculinity and femininity. Hegemonic masculinity is not, after all, an unassailable force, but one that must be continually enacted, pursued, and defended in a range of ways across the lifecourse.

I also want to make the case here that these strategies for (re) asserting male power are not only employed on a fictional level by the novel's central male characters: they are also undertaken on a metatextual level by Snow himself as the author of this fiction. Considering biographical information about C.P. Snow's life in conjunction with the novel-including his ready avowal of certain autobiographical elements in the story-I open up the potential for reading the book, in part, as an autoethnographic account of Snow's personal participation in the operations of hegemonic masculinity.

The medical novum of rejuvenation in New Lives for Old reflects Snow's interest in the possibility of a medical innovation to augment male erotic desire and sexual activity. At the novel's outset, Pilgrim's body is failing. He is old and balding, and his remembered sexual experiences are characterised by disgust and regret. He recalls 'futile burnings', the disappointments of previous sexual encounters, and a 'miserable marriage, a give-andtake affair with no glamour about it, and a few isolated passionate hours' (Snow, 1933d, pp. 26-27). While his younger colleague Callan exercises caution about the new scientific discovery, Pilgrim allows his own personal interests to influence his scientific judgement.

Rejuvenation does not just offer Pilgrim scientific fame and acclaim, but an opportunity for him to exert a sexual power he has struggled to assert. Once he has undergone the treatment, Pilgrim's initial experience is 'a renewed urge, and a renewed desire' to prove 'the press of manhood' (Snow, 1933d, p. 121). His rejuvenation is experienced as a carnal renaissance, an eruption of desire communicated in sexually-charged prose: 'It was delightful to linger on the brink and feel that life was long now, that there was time to lie about and play before the plunge into a relation which he knew was going to leave its mark upon the years to come' (p. 132). His physical relationship with the twenty-fouryear-old Alison offers a sharp contrast to the 'clumsy longings' of his previous courtships, and the comparison invokes a linear narrative of personal progress and triumph (pp. 132-33). Pilgrim's successful rejuvenation is contingent on Alison's sexual availability, and her sublimation. His relationship with her is the corollary and proof of his scientific experiment: 'the test which he had developed, which would satisfy him about his own new life, was to make love to Alison and have her for his own' (Snow, 1933d, p. 151).

Yet, no sooner has Pilgrim achieved this new state of sexual fulfilment, does it come under threat. 'A fundamental element of hegemonic masculinity', Donaldson (1993) writes, 'is that... women provide heterosexual men with sexual validation and men compete with each other for this' (p. 645). Such is the strength of Snow's interest in the vicissitudes of hegemonic masculinities that he shifts the plot focus entirely from socio-political interest in the scientific discovery, to the sexual rivalry between Pilgrim and his friend Vanden as they compete for Alison's affections. Vanden, a novelist, has a reputation as 'a callous, heartless pursuer of women', and Pilgrim resents him for having 'already taken more than his share of the pleasures' (Snow, 1933d, p. 31, 33). Vanden perceives an opportunity to assert a dominant masculinity by staking his own claim on Alison's passions. Part II of the novel focuses almost exclusively on the two men's respective love affairs with the same woman. In a scene in which Vanden delivers to Pilgrim the news that Alison has left him, the two men wrestle with the contradictory demands of friendship and male sexual ego. Vanden cycles through feelings of 'distress' and 'remorse', alongside 'satisfaction' and a 'fierce thrill' (pp. 144-145). In the outcome of the conversation, Pilgrim cedes his newly-discovered sexual jurisdiction to his friend. The power balance between the two men shifts again when Alison becomes unhappy in her relationship with Vanden and returns home to England. When she then begins to pick up the threads of her relationship with Pilgrim, Vanden watches with 'sick despair' (p. 236).

Pilgrim and Vanden's contest for validation through sexual competition represents one of the major practices through which the male characters of the novel seek to obtain, and defend, a hegemonic masculinity. However, even as these two men battle for prepotency, their relative dominance is affirmed through the juxtaposition of their shared combative sexual appetites with the sexual passivity of the novel's third male character: the twentyfive-year-old scientist David Callan. If a robust heterosexuality is the 'bedrock' of hegemonic masculinity (Donaldson, 1993, p. 645), then Callan's ascribed 'erotophobia' (Snow, 1933d, p. 69) consigns him readily to the realm of subordinate masculinities. In a novel about sexual rejuvenation replete with libidinous male behaviour, Callan is characterised variously as asexual and sexually incompetent. At the opening of the novel, it is Callan who is romantically involved with Alison. But together, Pilgrim and Vanden endeavour to neutralise the younger man's sexual power as they also seek to assert their professional and sexual authority. Callan is first introduced as a young scientist whose 'fierce' and 'fervent' passions are focused predominantly on his work (Snow, 1933d, p. 16). Other characters contribute to a profile of Callan as sexually inexperienced and romantically inept. Pilgrim surmises that the younger man has not had 'much of actual practical sex' (p. 52), whilst Vanden describes him as 'one of those people who are frightened of the body and tremendously fascinated by it at the same time' (p. 62). After discovering the new hormonal compound in his experiments with Pilgrim, Callan opposes the release of the new technique in part because he fears losing Alison to a more experienced, newly-rejuvenated male rival. In the eyes of this younger man, the new sexual technology of rejuvenation poses a profound threat to his sexual licence to the benefit of older suitors ('He saw before his eyes the old turning young, he imagined Alison with some old man. He had broken out wildly', p. 51). Hegemonic masculinity in the novel thus also operates through the relative demarcation of subordinate masculinity: Pilgram and Vanden's power is reified by Callan's sexual inferiority.

In addition to promoting a dynamic hierarchy of intermale dominance, hegemonic masculinity, as a feature of patriarchal 
power, also requires the formation of an ideal-and subordinate -femininity. Connell and Messerschmidt (2005) formulated the concept of a hegemonic masculinity and a hegemonic femininity in tandem, before renaming the latter 'emphasised femininity' to acknowledge 'the asymmetrical position of masculinities and femininities in a patriarchal gender order' (p. 848). Hegemonic masculinity operates to subordinate women through the creation and maintenance of 'emphasised femininity' as a social and aesthetic standard of female behaviour and presentation. New Lives for Old documents the continuous formulation of an emphasised femininity by a cast of male characters seeking to manage the disruptions to masculine agency and dominance heralded by the new rejuvenation technology.

At the points in the novel where female agency threatens to disrupt the enforced consent of hegemonic masculinity, the male characters yield, in turns, to the violent forces of contempt, jealousy, and fear. As Vanden's feelings for Alison develop, he seeks to reassert control by contemplating Alison's 'inadequacies and vulgarities', reflecting on her 'second-hand literary judgements of the stupider sort, and her father's Edwardian opinions on worldaffairs, and fragments of undergraduate free thought' which 'add a tawdriness to her effect' (Snow, 1933d, p. 179). At this stage in the narrative, the young Alison meets the physical criteria of desirable womanhood: intellect therefore frames the nature of this verbal attack. But when Alison separates from Vanden and rekindles her relationship with Pilgrim, the prospect that Vanden may reestablish his claim on her pushes Pilgrim to defend his hegemonic masculinity by force. Alison, whose choice of one man or the other is an unknown quantity to both, is the target of Pilgrim's aggression. He insists that she telephones Vanden to reject him definitively. When he discovers that she has not done so, his anger breaks, and he assaults her:

His fingers were gripping her painfully. She looked cowed and plaintive. He began to shake her and went on speaking fast: 'Have you got no imagination at all? Can't you ever see a bit further than yourself? He shook her, her teeth jarred on one another, she looked frightenedly into his reddened angry face. 'You little slut! Treating a man like that, without any imagination or manners or decency or anything else that makes life possible! [...] Like a silly schoolgirl who doesn't know that a man can feel! You ought to be beaten for it'-he went on shaking her-'you ought to be beaten. You mightn't understand why, but it would teach you to think next time'. He threw her back on the sofa, and stood up. (Snow, 1933d, p. 207)

In his analysis of historical, everyday, and theoretical constructions of men's violence to known women, the sociologist Jeff Hearn (1996) has observed that 'men often justify their violent behaviour as a response to feelings of frustration, anger or fear of a loss of power' (p. 27). Pilgrim's motivations are tangled: 'relief' at the elimination of a male sexual rival is offset by 'indignation' at the perceived position of sexual power Alison occupies as the object of both men's affections (Snow, 1933d, p. 270). Pilgrim attributes to Alison a callous disregard for male feeling that necessitates both verbal and physical punishment. In this deeply unsettling scene, hegemonic masculinity's recourse to violence is underwritten by Alison's internalised misogyny. Snow minimises and valorises this fictional scene of male violence by describing the female victim of that violence in a state of exhilarated compliance:

Alison stared at him. [...] The shaking, she did not mind at all; she wouldn't have been surprised, or particularly disturbed, if he had hit her [...] it was an exciting inconvenience. (Snow, 1933d, p. 271)
Pilgrim's physical assault of Alison is the violent apex of his ongoing efforts to maintain hegemonic masculinity. Later in the novel, he once again employs verbal strategies of degradation as a means to reassert a gendered authority that he feels Alison has compromised. Through Callan's retrospective musings in Part III of the novel, we learn that Alison had left Pilgrim 'quite suddenly, without a word, and no one knew where she had gone or to whom' (Snow, 1933d, p. 308). Despite his subsequent marriage to the 'diffident' Naomi (p. 326), Pilgrim's hostility towards Alison is expressed forcefully when he encounters her thirty years after the earlier events in the novel. He is ninety-five years old: Alison is fifty-four and has elected to age without rejuvenation treatment:

He looked round and saw a woman by his side. He realised, rather than saw, that it was Alison. Alison, grown to be a caricature of herself when young. In once glance, which hurt him as he looked, Pilgrim saw how the fat on her face had overlaid the smooth grave curves; through the paint, the skin was coarsely rough; of the face of Alison thirty years ago, nothing was left save the eyes. She was wearing a heavy fur coat, but underneath it she was fat and loose. She panted slightly as she talked. (Snow, 1933d, pp. 346-347)

In this passage, the aged male protagonist-whose own physical condition is neither described nor scrutinised-conceptualises female ageing as a condition of tragic dispossession, physiological depreciation. Drawing comparisons between Alison's appearance as a young woman of twenty-four and her current condition, Snow conceives female middle age as a catastrophic loss of aesthetic value so profound that it causes psychic injury to the male observer: Pilgrim's visual encounter with the older Alison 'hurt him as he looked'. Elsewhere, we are told he is 'in pain' from 'a joke that time had played' (Snow, 1933d, p. 347). Alison's body offends Pilgrim's sensibility because it is unrestrained: occupying space (fat and loose), audibly present (she panted slightly as she talked). This perceived corporeal excess jeopardises his balance and cheerful control (p. 348). It also destabilises the forward thrust of the narrative. A few paragraphs later, Snow circles back to Pilgrim's disgust, revisiting the critique of Alison's body with an unconcealed disgust: 'she was gross and clumsy, a fat woman'; 'It was pathetic, and obscene' (p. 348). Alison's unconstrained corporeality generates a corresponding lack of writerly control. In a third paragraph, Snow forsakes linguistic ingenuity for lazy repetition, subsumed by the conceptual affront of lost female youth: 'She was gross, and she panted as she talked' (p. 349). The ageing female body is the grotesque embodiment of what emphasised femininity is not.

There is, then, substantive textual evidence that New Lives for Old is not only an androcentric novel, but one in which the pursuit and defence of hegemonic masculinity in the face of rejuvenation technology elicits strategies of aggressive male competition, and the malign subordination of women. To what extent, though, can we pass judgement on Snow as the creative agent of this narrative? Is New Lives for Old a sexist novel? Or is its sexism confined to the diegesis? The misogynistic beliefs and acts outlined above can be attributed to fictional male characters. But the bromidic characterisation of the female protagonist, the lack of critical nuance in the depiction of male misogyny, and the diffidence of the novel's female characters to sexist disparagements, are all Snow's. Since Roland Barthes' injunction on the death of the author, interpreting a work of fiction with recourse to biographical information about the writer remains a fraught enterprise (Barthes, 1967). However, the author's correspondence with his publisher, read in conjunction with Snow's own reflection on his early romantic life, offer material context for the writer's gendered perspectives on rejuvenation I have explored here. 
In letters to Victor Gollancz about the manuscript for the novel, Snow revealed that the character of Alison was in fact based on a living person. 'The original of Alison has read the whole MS', he wrote, in seeking to assuage Gollancz's concerns about the possibility of libel claims arising from Snow's incorporation of real-life individuals into his characterisations (Snow, 1933b). There is strong circumstantial evidence to suggest that this 'living person' was Stella Eames, a young woman with whom Snow was romantically involved before he left Leicester for Cambridge, and whom he continued to see, on and off, throughout the period in which he was writing New Lives for Old: the book's dedication was 'To Stella, and her life ahead' (Halperin, 1983 , p. 125, 27; Snow, 1982, p. 35). In the Halperin interview, Snow, looking back on his romantic history, admitted to a certain insecurity in the company of women as a young man. 'I was in search of beauty, which is a very foolish thing to be in search of, he reflected, noting that he had since decided that 'what was necessary was someone you were happy in bed with' (Halperin, 1983 , p. 67). He also recalled that he wanted to marry Stella 'very badly', but that she would not say yes (p. 68), and that the relationship cast a shadow over his first years as a scientist at Cambridge; 'I was pretty miserable about Stella a lot of the time', he remembers (p. 85), adding that 'I tried to see her, but I did have one or two girls for purely carnal entertainment' (p. 41). Snow was navigating the dynamics of hegemonic masculinity in a fictional context through authorship of New Lives for Old at the same time as he was negotiating the complexities of a real-life romantic relationship with a young woman who eluded his ardent interest.

In the year that he was working on the manuscript for New Lives for Old, Snow was also undertaking research in photochemistry with his colleague Philip Bowden. The two young scientists believed they had discovered a way to artificially synthesise Vitamin A and published their findings in the journal Nature in May 1932. A press release led to widespread coverage of their findings in newspapers, in the Lancet and in the British Medical Journal. (De la Mothe 1983, pp. 133-134; Tredell, 2012, p. 14). But within two weeks, two senior scientific experts on the organic chemistry of vitamins had disproved their claims. Referring to this period of his life, Snow later recalled 'I was extremely miserable. Everything, personal and creative, seemed to be going wrong' (Snow, 1971, Preface). He turned his hand to writing, drawing on the experience of the Vitamin A debacle in the early pages of New Lives for Old, where Pilgrim and Callan wrestle with the moral and professional consequences of announcing their findings.

We might be tempted to regard New Lives for Old, first and foremost, as a testing-ground for the biocultural concept of rejuvenation, and for the ethical and social implications of medical interventions in the life course. The novel certainly represents a discursive engagement with ongoing debates about the value and purpose of science in a changing world. It is also part of a wider family of fictional texts in the subgenre of rejuvenation fiction which have their roots in the social, institutional, and literary contexts of early-twentieth-century British society. But the biographical details of C.P. Snow's life and the structures of male privilege within which he was embedded are integral to a more nuanced understanding of the novel's medical novum, and the real-life scientific practices that inspired it. To read this particular rejuvenation fiction, then, is to also engage with a fantasy of reasserted agency by a man disempowered in intellectual, homosocial and heteronormative terms: a scholar who had been discredited in the elite male-dominated scientific research culture of early twentieth-century Cambridge academe, and refused by the woman whose will and affections he could not subordinate to his own.
Received: 4 March 2018 Accepted: 31 May 2018

Published online: 17 July 2018

\section{Notes}

1 Ramanathan (1978) omitted the book from his 1978 study on the grounds that it did not represent a 'serious preoccupation' (p. ix). Twenty years later, De la Mothe (1992) followed suit, mentioning it only in passing-as a 'mediocre' achievement (p. 13).

2 O'Brien had published her novel Without My Cloak (1931) with the company the previous year and would continue to work with them on her literary output until the $1960 \mathrm{~s}$

3 For more on these intellectual and public debates, see De la Mothe (1992, pp. 36, 40-46, 109); Werskey (1978); Collins (1979).

4 'There is a certain amount of introduction of famous people by their own names, or under thin disguises', Gerald Gould warned Gollancz, citing the obvious parody of Labour Prime Minister Ramsey MacDonald in the fictional character of the former socialist Lancing Kittigrew, and a named appearance from Ernest Rutherford,

Director of the Cavendish Laboratory at Cambridge where Snow had worked (Gould 1933, p. 6).

5 The book is not referenced or discussed in the John Halperin's oral biography transcripts (1983).

6 For an overview of the rejuvenation fiction subgenre and scholarship on individual texts, see Oakley (2016, pp. 141-199). Sengoopta (2006) offers the most extensive overview of rejuvenation as a medical phenomenon.

7 On Brown-Séquard, see Borrell (1976). For fiction, see short stories by Robert Duncan Milne, 'The Man Who Grew Young Again' (1887), Mary Elizabeth Braddon 'Good Lady Ducayne' (1896), Jack London 'The Rejuvenation of Major Rathbone' (1889) and Eliza Lynn Linton's novel The Second Youth of Theodora Desanges (1899). Milne and Braddon's stories are two examples of fiction from the fin-de-siècle that feature rejuvenation by blood transfusion discussed in Oakley (2018).

8 For a summary overview of the work of Steinach and Voronoff, see Kozminski and Bloom (2012).

9 Marie Corelli's The Young Diana (1922) and Gertrude Atherton's Black Oxen (1923) were both adapted into successful Hollywood films. Bertram Gayton's The Gland Stealers (1922) and Arthur Conan Doyle's 'The Adventure of the Creeping Man' (1923) are other notable fictions from this phase of the genre.

10 The critic in the Saturday Review compared Mitchell's book unfavourably with Snow's, lamenting that Yet in My Flesh was an 'unpleasant account' that featured 'too much about bodies and biology at least for one taste'. (A.B., 1933b). Snow's vagaries on male rejuvenation, published the following month, proved more of a success for that reviewer, who commended New Lives for Old as the ' "definitive" novel about rejuvenation, the offspring of good science and bubbling imagination' (A.B., 1933a).

11 New Worlds for Old was a particular success, reprinted and updated for a number of years after its initial publication (see Sherborne, 2010, p. 185).

12 Although women were first admitted to the Oxford and Cambridge in the mid-to-late nineteenth century, their access to higher education remained piecemeal throughout the early-twentieth century, and they would not be awarded degrees on an equal basis to men at Cambridge until 1948.

\section{References}

A.B. (1933a) Fare for the novel reader. Saturday review of politics, literature, science and art. Vol 158. British Periodicals Online

A.B. (1933b) New novels. Saturday review of politics, literature, science, and art. Vol 627. British Periodicals Online

Afanasyeva N (2002) C. P. Snow and H. G. Wells: a history of their acquaintance, friendship and influence. The Wellsian 25. community.dur.ac.uk/time. machine/OJS/index.php/Wellsian/article/view/115/113

Ahmed S (2017) Living a feminist life. Duke University Press, Durham and London Anon (2018) Feminist history of science. In: Science Encyclopedia. http://science. jrank.org/pages/11233/Science-History-Feminist-History-Science.html. Accessed 25 June 2018

Atherton G (1923) Black oxen. Boni and Liveright Publishers, New York, NY

Barthes R (1967) The death of the author. Aspen. http://www.ubu.com/aspen/ aspen5and6/threeEssays.html\#barthes. Accessed 25 June 2018

Black Oxen (1923) Film, USA: Frank Lloyd

Borrell M (1976) Brown-Séquard's organotherapy and its appearance in America at the end of the nineteenth century. Bull Hist Med 50(3):309-320. http://www. jstor.org/stable/44451276

Braddon ME (1896) Good Lady Ducayne. The Strand Magazine, p. 185-199

Carrigan T, Connell B (1985) Toward a new sociology of masculinity. Theory Soc 14(5):551-604. http://www.jstor.org/stable/657315

Collins P (1979) The British Association for the Advancement of Science [BAAS] and Public Attitudes to Science, 1919-1945. D.Phil, University of Leeds, UK. http://etheses.whiterose.ac.uk/4621/1/uk_bl_ethos_574464.pdf 
Conan-Doyle A (1923) The adventure of the creeping man. The Strand Magazine, p. $210-224$

Connell RW, Messerschmidt JW (2005) Hegemonic masculinity: rethinking the concept. Gend Soc 19(6):829-859. https://doi.org/10.1177/0891243205278639

Crasnow S et al. (2015) Feminist perspectives on science. Stanford Encyclopedia of Philosophy. https://plato.stanford.edu/entries/feminist-science/. Accessed 25 June 2018

Csicsery-Ronay Jr., I (2003) Marxist theory and science fiction. In: James E and Mendlesohn F (eds) The Cambridge companion to science fiction. Cambridge University Press, Cambridge, UK, pp 113-124

De la Mothe J (1992) C.P. Snow and the struggle of modernity. University of Texas Press, Austin, Tex

Devitt A (2004) Writing genres. Southern Illinois University Press, Carbondale

Donaldson M (1993) What is hegemonic masculinity? Theory Soc 22(5):643-657. https://doi.org/10.1007/BF00993540

Gayton B (1922) The gland stealers. JB Lippincott Company, London

Gollancz V (1933). [Letter] Letter from Victor Gollancz to C.P. Snow. Orion Publishing Group, Gollancz Archive, 'New Lives for Old (1933)' file

Gould G (1933) Reader's report. Orion Publishing Group, Gollancz Archive, 'New Lives for Old (1933)' file

Gramsci A (1998) Selections from the prison notebooks of Antonio Gramsci. Lawrence and Wishart, Ltd., London

Halperin J (1983) C.P. Snow: an oral biography. Harvester Press, Brighton

Hamilton D (1986) The monkey-gland affair. Chatto and Windus, London

Hearn J (1996) Men's violence to known women: Historical, everyday and theoretical constructions of men. In: Fawcett B et al. (ed) Violence and gender relations: theories and interventions. Sage Publications, London, pp. 22-37

Huxley A (1932) Brave new world. Flamingo, London

Jones ECB (1933) New novels. The New Statesman and The Nation, p. 136

Kozminski MA, Bloom DA (2012) A brief history of rejuvenation operations. J Urol 187(3):1130-1134. https://doi.org/10.1016/j.juro.2011.10.134

Linton EL (1899) The second youth of Theodora Desanges. Hutchinson \& Co., London

London J (1889) The rejuvenation of major rathbone. Conkey's Home Journal, vol 6

Miller CR (1984) Genre as social action. Quart J Speech 70(2) 1984: 151-167. https://doi.org/10.1080/00335638409383686.

Milne RD (1887) The man who grew young again. The Argonaut, p. 4-6

Mitchell M (1933) Yet in my flesh. J.M. Dent, London

Oakley C (2018) Towards cultural materialism in the medical humanities: the case of blood rejuvenation. Med Humanit 44(1):5-14. https://doi.org/10.1136/ medhum-2017-011209

Oakley C (2016) Vital forms: bodily energy in medicine and culture, 1870-1925. D. Phil, University of York, UK. http://etheses.whiterose.ac.uk/16647/

O'Brien K (1931) Without my cloak. William Heinemann, London

O’Brien K (undated) Reader's report. Orion Publishing Group, Gollancz Archive, 'New Lives for Old (1933)' file

Oudshoorn N (1994) Beyond the natural body: an archaeology of sex hormones. Routledge, London

Ramanathan S (1978) The novels of C.P. Snow: a critical introduction. Macmillan, London

Ryan ML (1981) Introduction: on the what, why, and how of generic taxonomy. Poetics 10(2-3):109-126. https://doi.org/10.1016/0304-422X(81)90030-9

Sengoopta C (2006) The most secret quintessence of life: sex, glands, hormones, 1850-1950. University of Chicago Press, Chicago, Ill

Sherborne D (2010) H.G. Wells: another kind of life. Peter Owen, London

Snow CP (1933a) [Letter] Letter from C.P. Snow to Victor Gollancz. Orion Publishing Group, Gollancz Archive, 'New Lives for Old (1933)' file

Snow CP (1933b) [Letter] Letter from C.P. Snow to Victor Gollancz. Orion Publishing Group, Gollancz Archive, 'New Lives for Old (1933)' file

Snow CP (1933c) [Letter] Letter from C.P. Snow to Victor Gollancz. Orion Publishing Group, Gollancz Archive, 'New Lives for Old (1933)' file
Snow CP (1959) The two cultures and the scientific revolution. Cambridge University Press, Cambridge

Snow CP (1933d) New lives for old. Gollancz, London

Snow CP (1932) Death under sail. Heinemann, London

Snow CP (1971) Strangers and brothers, Omnibus edn. vol 1. Charles Scribner's Sons, London

Snow P (1982) Stranger and brother: a portrait of C.P. Snow. Macmillan, London Squier SM (2004) Liminal lives: imagining the human at the frontiers of biomedicine: Durham, N.C.: Duke University Press, pp. 146-167

Suvin D (1979) Metamorphoses of science fiction: on the poetics and history of a literary genre. Yale University Press, New Haven and London

The Young Diana (1922) [Film] USA: Albert Capellani and Robert.G. Vignola

Tredell N (2012) C.P. Snow: the dynamics of hope. Palgrave, London

Waldby C (2000) The visible human project: informatic bodies and posthuman medicine. Routledge, New York, NY, and London

Waldby C (1996) AIDS and the body politic: biomedicine and sexual difference. Routledge, London

Wells HG (1914) The world set free. Macmillan and Co., London

Wells HG (1910) The sleeper awakes. T. Nelson, London

Wells HG (1908) New worlds for old. Macmillan, London

Wells HG (1895) The time machine. William Heinemann, London

Werskey G (1978) The visible college: a collective biography of british scientists and socialists of 1930s. Allen Lane, London

Willis M (2006) Mesmerists, monsters, and machines: science fiction and the cultures of science in the nineteenth century. Kent State University Press, Kent OH

\section{Acknowledgements}

With special thanks to Malcolm Edwards, Chairman of Gollancz and Consultant Publisher at Orion Books, for facilitating access to archival materials cited. This work was supported by the Arts and Humanities Research Council (grant number: AH/N007735/ 1). The open access publication costs for this paper are covered by a Wellcome Trust grant $(108342 / \mathrm{Z} / 15 / \mathrm{Z})$

\section{Additional information}

Competing interests: The author declares no competing interests.

Reprints and permission information is available online at http://www.nature.com/ reprints

Publisher's note: Springer Nature remains neutral with regard to jurisdictional claims in published maps and institutional affiliations.

\begin{abstract}
Open Access This article is licensed under a Creative Commons BY Attribution 4.0 International License, which permits use, sharing,
adaptation, distribution and reproduction in any medium or format, as long as you give appropriate credit to the original author(s) and the source, provide a link to the Creative Commons license, and indicate if changes were made. The images or other third party material in this article are included in the article's Creative Commons license, unless indicated otherwise in a credit line to the material. If material is not included in the article's Creative Commons license and your intended use is not permitted by statutory regulation or exceeds the permitted use, you will need to obtain permission directly from the copyright holder. To view a copy of this license, visit http://creativecommons.org/ licenses/by/4.0/
\end{abstract}

(c) The Author(s) 2018 